\title{
Journal of the International Society

\section{The effects of a starch based carbohydrate alone or in combination with whey protein on a subsequent bout of exercise performance - preliminary findings}

\author{
Paul La Bounty*1, Matt Cooke ${ }^{1}$, Bill Campbell ${ }^{2}$, Josh Vanta ${ }^{1}$, Haleigh Mistry ${ }^{1}$, \\ Mike Greenwood ${ }^{1}$, Rafer Lutz ${ }^{1}$ and Darryn Willoughby ${ }^{1}$
}

\author{
Address: ${ }^{1}$ Baylor University - Exercise and Biochemical Nutrition Laboratory, Waco, TX, USA and ${ }^{2}$ University of South Florida - Exercise and \\ Performance Nutrition Laboratory, Tampa, FL, USA \\ Email: Paul La Bounty* - Paul_La_Bounty@baylor.edu \\ * Corresponding author
}

from 2009 International Society of Sports Nutrition Conference and Expo

New Orleans, LA, USA. 14-15 June 2009

Published: 31 July 2009

Journal of the International Society of Sports Nutrition 2009, 6(SuppI I):PI3 doi:I0.1 I86/I550-2783-6-SI-PI3

This abstract is available from: http://www.jissn.com/content/6/SI/PI3

(c) 2009 La Bounty et al; licensee BioMed Central Ltd.

\section{Background}

High-molecular weight, starch based carbohydrates have been shown to leave the stomach faster as well as replenish muscle glycogen more rapidly as compared to lower molecular weight, monomeric glucose and short-chain glucose oligomers (Leiper, et al. 2000 and Piehl Aulin et al. 2000). Furthermore, it has been shown that Vitargo (a high molecular weight, low osmolality starch based carbohydrate) led to a greater work-output during a 15 minute time-trial 2 hours following cycling to exhaustion when compared to maltodextrin (a low molecular weight carbohydrate) (Stephens et al. 2008). The purpose of this study was to replace a portion of a high-molecular weight carbohydrate with whey protein to determine if it could enhance muscle glycogen re-synthesis following a heavy resistance training bout and/or enhance a subsequent bout of exercise (15 min cycle ergometer time trial) 2 hours later.

\section{Methods}

10 recreationally active, fasted males ( 21.5 years; 178.1 $\mathrm{cm} ; 79.5 \mathrm{~kg}$ ) performed 5 sets of hack squats, 5 sets of leg press, and 5 sets of leg extension at $80 \%$ of 1 RM to failure (in attempt to reduce muscle glycogen content). Rest periods between sets and exercises were 150 seconds. Immediately following the RT bout, participants were blockrandomized to consume a 1 liter solution containing either $1.0 \mathrm{~g} / \mathrm{kg}$ of carbohydrate from Vitargo ${ }^{\circledR} \mathrm{S} 2$ or $0.75 \mathrm{~g} /$ $\mathrm{kg}$ of carbohydrate from Vitargo ${ }^{\circledR} \mathrm{S} 2+0.25 \mathrm{~g} / \mathrm{kg}$ of a commercially available whey protein product (whey protein isolate, whey protein concentrate, and whey protein hydrolysates). Both supplements were $\sim$ isocaloric. Exactly one week later, the participants performed the same resistance training (RT) protocol, but consumed the second solution. After consuming the supplement, the subjects rested in a semi-supine position for 2 hours. Following the rest period, the participants performed a 15 minute time trial on a cycle ergometer. The time-trial was programmed in a pedaling dependent mode, in which an increase in pedaling rate increased the work rate. Total work $(\mathrm{kJ})$ was recorded at 5,10 , and 15 minutes. A twoway $(2 \times 3$-supplement $\times$ time $)$ ANOVA with repeated measures was utilized to analyze the data using SPSS 16.0.

\footnotetext{
Results

Data are reported as means \pm SD at 5, 10, and 15 minutes during the time-trial. Total work was $53.4 \pm 13.7,102.7 \pm$ $27.4,150.8 \pm 41.2$ and $52.1 \pm 13.6,100.8 \pm 28.1,149.7 \pm$ 42.5 for the Vitargo ${ }^{\circledast}$ S2 and Vitargo ${ }^{\oplus}$ S2 + whey protein groups, respectively. A significant main effect for time was observed ( $p<0.001$ ), but no significant main effect for treatment $(\mathrm{p}=.550)$ or significant treatment ${ }^{*}$ time interaction $(\mathrm{p}=0.798)$ was observed for total work $(\mathrm{kJ})$.
} 


\section{Conclusion}

Consuming $0.75 \mathrm{~g} / \mathrm{kg}$ of carbohydrate from Vitargo ${ }^{\circledast} \mathrm{S} 2+$ $0.25 \mathrm{~g} / \mathrm{kg}$ of whey protein does not enhance a subsequent bout of exercise performance above that observed when 1 $\mathrm{g} / \mathrm{kg}$ of carbohydrate from Vitargo ${ }^{\oplus} \mathrm{S} 2$ alone was consumed.

\section{Acknowledgements}

This study was supported by funds from the Baylor University Research Committee and the Vice Provost for Research.

Publish with Biomed Central and every scientist can read your work free of charge

"BioMed Central will be the most significant development for disseminating the results of biomedical research in our lifetime. " Sir Paul Nurse, Cancer Research UK

Your research papers will be:

- available free of charge to the entire biomedical community

- peer reviewed and published immediately upon acceptance

- cited in PubMed and archived on PubMed Central

- yours - you keep the copyright 